\title{
ACADEMIC SDI: A PROPOSAL FOR THE FEDERAL UNIVERSITY OF PARANÁ (UFPR)
}

Adriana Alexandria Machado ${ }^{1}$ - ORCID: 0000-0003-1013-2050

Silvana Philippi Camboim ${ }^{1}$ - ORCID: 0000-0003-3557-5341

${ }^{1}$ Universidade Federal do Paraná, Programa de Pós-Graduação em Ciências Geodésicas, Curitiba, PR, Brazil.

E-mail: adri.alexandria@gmail.com, silvanacamboim@gmail.com

Received in $25^{\text {th }}$ June 2018

Accepted in $15^{\text {th }}$ February 2019

\section{Abstract:}

Although universities conduct research in the SDI field, they have repeatedly erred when storing, preserving, and sharing their geospatial data. The general objective of this research is to develop a proposal for a Spatial Data Infrastructure (SDI) for the graduate programs of the Department of Earth Sciences at Federal University of Paraná (UFPR). In order to initiate the process of implementing UFPR's academic SDI, a sample of the theses and dissertations of the aforementioned programs was collected. Subsequently, a survey of the metadata of the spatial study areas and publications was conducted, and finally, these metadata were made available as a catalog through GeoNetwork. The metadata, ISO TC-221, OGC and WC3 standards recommended by INDE-BR were adopted, and free and open source software was used. In this paper, the results of the metadata survey and their availability are presented in the form of a catalog, as well as a synthesis of the reflections made during the execution of the research, in order to help define the characteristics of academic SDIs in the country. The cataloging of historical metadata was found to be viable and to facilitate the dissemination of geospatial data to the scientific community.

Keywords: Spatial Data Infrastructure (SDI); UFPR's Academic SDI; Academic SDIs in Brazil; Brazilian National Spatial Data Infrastructure (INDE-BR); Geospatial research data; Metadata. 


\section{Introduction}

In 2008, the National Spatial Data Infrastructure (INDE-BR) was instituted in Brazil, via decree $6.666 / 08$, with the objective of "facilitating and ordering the generation, storage, access, sharing, dissemination, and use of geospatial data of federal, state, district, and municipal origins" (Brasil2008). The decree establishes that participation is mandatory for the federal public institutions and voluntary for the other hierarchies, the private sector and civil organizations.

There are five pillars of Spatial Data Infrastructure (SDI): actors, data, institutional, technologies, and norms and standards. Actors can play different roles, among them: organizational and administrative; enablers; producers; users; and providers of products and services. These actors include the public sector, the private sector, the academia, and users.

In relation to the academia, which is the focus of this study, the University's role is synthesized through three inseparable processes: Teaching, Research and Extension (community services) (Brasil 1988). These activities play a significant role in the production and use of geospatial data. Through them, universities collect data, analyze, generate knowledge, and to supply the society with information and recommendations for a public policy (Davis Jr., Fonseca and Câmara 2009).

Considering the pillars of a SDI and the role of the University, its contribution to the development of SDIs can be established, as seen in Figure 1.

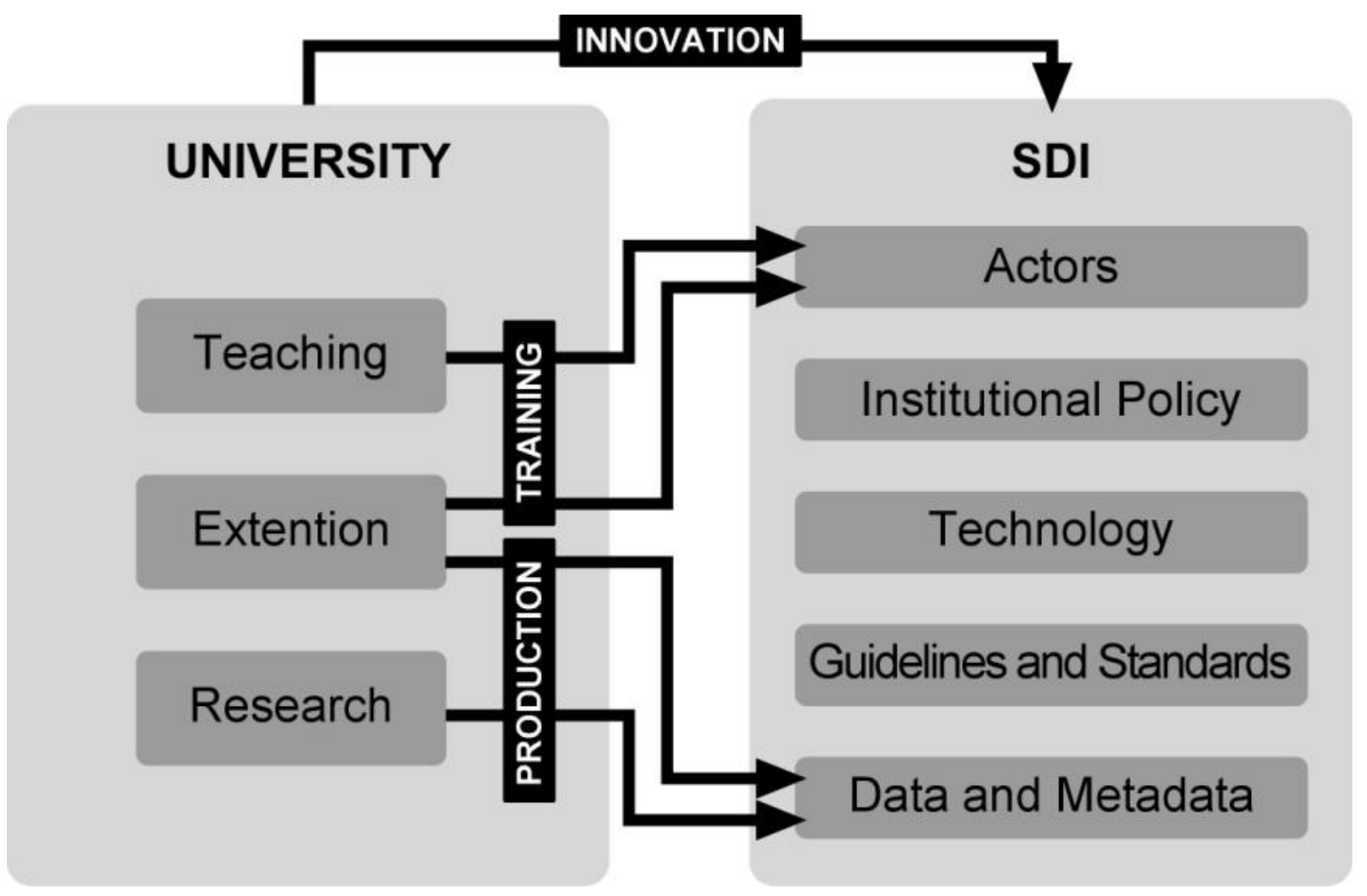

Figure 1: Relationship between University and SDI.

Source: Adapted from Brito et al. (2014). 
Teaching and Extension activities enable and sensitize its actors, whether they are creators, users, producers or providers of spatial data. Research and Extension activities produce data and metadata that can feed a SDI. In addition, the University is an environment that favors experiments that lead to innovations, advances and adaptations in all aspects related to SDIs, from institutional policy to the definition of norms and standards (Brito et al. 2014).

However, despite the fact that universities carry out research in the SDls field, they repeatedly make the mistake of not storing, preserving, nor sharing their geospatial data. These are usually scattered and isolated within several departments of the University, and as the data are stored inadequately, there is great difficulty in recovering them (Brito et al.2014; Davis Jr., Fonseca and Câmara 2009).

This situation has also been a concern of the Open Science movement, defined by (Foster 2018) as "the practice of science in such a way that others can collaborate and contribute, where research data, lab notes and other research processes are freely available, under terms that enable reuse, redistribution and reproduction of the research and its underlying data and methods". Open Science encompasses guidelines for other movements such as: Open Access, which refers to permanent online access to the full text of scholarly works, especially free publications for readers and libraries; Open Data, which refers to open access to data sets; and Open Source, which refers to free access to the source code for algorithms and software (Marwick et al. 2017; Fecher and Friesike2014).

Although access to academic data is considered important, current sharing practices are still not common and the volume of shared data varies among different scientific fields (Nosek et al. 2015; PRC 2010; Tenopir et al. 2011; Arzberger et al. 2004). There are specific reasons why researchers choose not to share their data and frequently the expectation of future publication opportunities (Tenopir et al. 2011; Savage and Vickers 2009). Policies and practices, which are determined by funding agencies, also have an influence on sharing, especially regarding intellectual property (Berman and Cerf 2013; Campbell et al. 2003).

In Brazil, according to the National Council for Scientific and Technological Development (CNPq), one of the country's main research funding agencies, it is the researcher's responsibility to communicate to CNPq whether the execution of the project will produce results protectable as intellectual property, in addition to ensuring the protection of projects financed by CNPq. Except for these cases, the resolution states that information generated through implementing the selected proposals, which are made available in the CNPq database, are considered open to public access. The resolution also states that despite the predicted possibility of restricting public access:

it does not, however, reduce the responsibility that researchers, their teams and institutions have as members of the research community to maintain, whenever possible, research results, data and collections available to other researchers for academic purposes. (Brasil 2011a).

The Coordination for the Improvement of Higher Education Personnel (Capes), which is another funding agency in Brazil, published on 02/25/2014 on its website (http://www.capes.gov.br) that, as of this date, "the Theses Bank is made available to the academic community, where all papers produced in Brazilian graduate courses will be yearly available for consultation". Through this new tool, information such as abstract, supervisor, evaluation board, keywords, area of knowledge, teaching institution, and line of research are made available. 
The integration of data from several producers with different technical characteristics, defined by the use for which they were primarily intended, requires information and knowledge to adapt them to new uses. Metadata is the information needed to facilitate this process, and it is also essential in the management of geospatial data, facilitating its reuse and dissemination. However, according to some research, the production of metadata is still not usual in institutions.

A survey of scientific data practices, conducted with 1,329 students, researchers, and professors from various universities in the United States, between October 2009 and July 2010, has revealed that $26 \%$ of respondents were satisfied with the tools to produce metadata, while $32 \%$ were dissatisfied. According to the authors of the survey, the large number of respondents who answered that they "did not agree nor disagree" (42\%) regarding their satisfaction with such tools could be interpreted in two ways: respondents were either truly indifferent or unsure of what metadata meant. The authors argue that the second option is most likely to be true, since $46 \%$ of respondents answered "none" to the question "What metadata do you normally use to describe your data?" (Tenopir et al. 2011).

Currently in Brazil, the possible metadata produced in the academia are the information contained in the catalographic cards required by university libraries. However, it is not detailed in the catalographic cards which publications contain geospatial data. The nature of geospatial data demands specific information that is not part of the metadata standards for other types of publications and data. Thus, the information that currently exists is not enough to allow the reuse of the geospatial data produced in academia.

Scientific data, whether geospatial or not, should return value to society either because they are produced through public funding or because one of the pillars of the University - Extension Education - have the role of articulating Teaching to the demands of the reality in which it is inserted (Martins 2008).

Therefore, an academic SDI is relevant. SDIs have the potential to become fundamental elements for understanding space, disseminating data and spatial information associated with metadata about origin, quality, and semantic descriptions (Borba, Strauch and Souza 2014).

A SDI especially designed for the academic environment would be interesting for the community, firstly because the reanalysis of the data helps to verify the results, which is a key part of the scientific process. Secondly, different interpretations or approaches to existing data contribute to scientific progress, especially in an interdisciplinary context. In addition, if well managed, long-term preservation helps maintain data integrity. Another important aspect is that when data is available, its efforts of regathering is minimized, so the use of human and financial resources is optimized. The availability of data provides protection against misconduct related to the creation and falsification of data. Moreover, the replication of scientific studies serves as support material and training tool for the new generations of students and researchers (Marwick et al. 2017; Fecher and Friesike 2014; Brito et al. 2014; Bernard et al. 2014; Tenopir et al. 2011).

There are experiences of portals and international academic SDIs such as those of the universities of Twente and Groningen in the Netherlands, Ostrava in the Czech Republic, CSIR in South Africa, Center for Sustainable Urban Development in Chile (Coetzee et al. 2017), the national GeoVITe (Iosifescu-Enescu et al. 2017), the GoGeo, a joint effort between the EDINA National Data Center of the University of Edinburgh in the United Kingdom and the UK Data Archive, University of Essex (Smyth 2015; Medyckyj-Scott 2004), the Canadian Scholars Geoportal in Canada (Hill and Trimble2012), the transnational IDE-Univers Project that brings together institutions from Spain, 
Greece and Italy (Barea et al. 2011) and the Australian Spatial Research Data Commons (ASRDC) from Australia (Kethers et al. 2010), among others.

There are already three Brazilian universities that are part of INDE-BR through the signature of the term of agreement to INDE-BR, the University of Rio de Janeiro (UERJ), the Federal University of $A B C$ (UFABC) and the University of Brasilia (UNB) (INDE2018). This is still a small number, either due to the fact that the discussion that the University should also be considered a producer of geospatial data is relatively recent (Brito et al. 2014); or that the structuring of an academic SDI presents several peculiarities, among them the organization of old data and the recovery of metadata (Fecher and Friesike 2014; Oliveira and Ramos 2013).

The general objective of this research is the development of a proposal for a SDI for the graduate programs of the Department of Earth Sciences of the Federal University of Paraná (UFPR). To initiate the process of implementing the SDI, the spatial metadata collected during the last seven years of the theses and dissertations of the aforementioned programs were made available in catalog form. In this paper, the results of the survey of metadata from theses, dissertations, and from their respective study areas, as well as the catalogued results of metadata availability are presented.

Implementing UFPR's academic SDI (SDI UFPR www.idea.ufpr.br) is part of a broad context within the scope of the Open Geospatial Laboratory (Laboratório Geoespacial Livre - UFPR) of the Geo for All Network, which aims to be a reference for the use of free technology and open source software. Within the Open Geospatial Laboratory and the Graduate Program in Geodetic Sciences, more functionalities like Web Map Service (WMS), Web Feature Service (WFS)and other geoservices have already been added through the Geonode platform to the SDI-UFPR by masters, doctorate, and scientific/technological research such as (Fronza 2016; Silva and Camboim, 2018). The catalogue was implemented through Web Catalog Service (CSW) and allows the metadata to be colected and harvested by INDE-BR and in the future by other universities and open data portals.

This paper is structured as follows: Chapter 2 presents a synthesis of the characteristics that define an academic SDI at a national level and constitutes the most important contribution of this research; Chapter 3 describes the methodology, which begins with the contextualization of the study area and is divided into three parts (survey of theses and dissertations, survey of the metadata of study areas and publications, and availability of metadata in catalog). In chapter 4 the results were presented and discussed, following the same division of methodological steps. Finally, chapter 5 presents the conclusions.

\section{Characterization of Academic SDIs in Brazil}

According to (Coetzee et al. 2017), the purpose of the academic SDI is "to make geospatial data produced for and by research and education discoverable, accessible and usable, primarily within universities and research institutes, but sometimes also for a wider audience, such as the general public". However, this definition can be adapted according to specific legislation and guidelines of each country. Figure 2 summarizes the reflections made during the execution of the research as a whole, in order to help define the characteristics of academic SDIs in Brazil in comparison to general aspects of INDE-BR. The analyzed aspects were the five pillars of an SDI: 
actors, data, institutional, technologies, and norms and standards. Apart from these, legislation, transparency and copyright, and quality were also analyzed.

Technologies were analyzed along with norms and standards, since INDE-BR recommends observing the standards and specifications proposed by it in the technological aspect also. Legislation refers to the country's present laws. Transparency and copyright represent important data sharing issues such as restrictions, responsibilities, and licenses for use of geospatial data.

In the figure, each of the afore mentioned aspects were analyzed and compared in relation to the national SDI (INDE-BR) since it is understood that the SDIs of the other hierarchies in the country should follow the standards, specifications and standards recommended by it (Brasil 2008). In the context of this research was used the national metadata standard, the MGB Profile (CONCAR 2009). In Brazil the institution responsible for the elaboration of the National Terrestrial Cartography Technical Normative Instructions is the National Cartography Commission (CONCAR) and all the standards, norms and specifications in the country must be approved by it (Brasil 1984).

INDE-BR is in line with the Open Data Policy in Brazil and thus complies with the Electronic Government Interoperability Standards, named e-Ping, that regulates the use of Information and Communication Technology in the federal government (CONCAR 2010); the National Open Data Infrastructure (INDA), which establishes "a set of standards, technologies, procedures and control mechanisms necessary to meet the conditions of dissemination and sharing of data and public information in the Open Data model" (Brasil 2012); and the Law on Access to Information, that aims to guarantee citizens the exercise of their right of access to public information (Brasil 2011b).

The INDE-BR's architecture defines that each set of servers under the responsibility of an institution providing data and geospatial metadata is called "node". In order for this institution to be considered a node of INDE-BR, it is necessary that it meets the five functionalities described in "transparency and copyright" in Figure 2 and formalize its participation by signing the Term of Adhesion to INDE-BR.

Thus, in summary, it is possible to define an academic SDI in Brazil as a SDI composed of data produced in the academia, following the definitions of standards established by INDE-BR and especially concerned with meeting the specific needs of the academic community. 


\begin{tabular}{|c|c|}
\hline INDE-BR & ACADEMIC SDIs \\
\hline $\begin{array}{l}\text { Actors: Governmental institutions, the academic sector, the } \\
\text { private sector and society in general. SDIs are designed to } \\
\text { assist all types of users. Designed by experts, they are usually } \\
\text { complex and require specialized knowledge to be managed. }\end{array}$ & $\begin{array}{l}\text { Actors: Higher education institutions, their researchers, professors, students, } \\
\text { staff, and society in general. These actors are, at the same time, users and } \\
\text { producers. They need geospatial data for teaching and research. }\end{array}$ \\
\hline $\begin{array}{l}\text { Data: In general, there is a clear distinction between the official } \\
\text { producers of reference data and of thematic data, although } \\
\text { there are proposals for integration of users who are producers } \\
\text { of volunteered geographic information (VGI). }\end{array}$ & $\begin{array}{l}\text { Data: Thematic data are produced in the most diverse areas of knowledge } \\
\text { and, often, in a single product. Besides traditional geospatial data, such as } \\
\text { vector and raster files, methodological proposals, raw data, reports of various } \\
\text { stages, computational systems are also produced. Hence, an academic SDI } \\
\text { must have the ability to handle all the production history of scientific geospatial } \\
\text { data to ensure their reproducibility. }\end{array}$ \\
\hline $\begin{array}{l}\text { Institutional: Government initiatives with centralized management, } \\
\text { starting from the highest hierarchy towards the lowest one with a } \\
\text { focus on data. The initiatives rely on their integration with the strategic } \\
\text { planning of the institution involved. They may be subject to variations } \\
\text { in support to the SDI with the alternation of the institution's } \\
\text { management. The official membership is centered in the institution. }\end{array}$ & $\begin{array}{l}\text { Institutional: Independent and collaborative initiatives within the universities, } \\
\text { with decentralized management. They tend to be focused on the needs of } \\
\text { their users. As any SDI, they need support for their expansion and strengthening. } \\
\text { The proposal of membership to the INDE-BR, separated for each university, } \\
\text { would collaborate to ensure the autonomy of the institutions. }\end{array}$ \\
\hline $\begin{array}{l}\text { Guidelines and standards: Guidelines, standards and } \\
\text { international specifications are adopted for interoperability and } \\
\text { technological aspects, as well as for those aspects concerning } \\
\text { the production techniques in the country. There is also the } \\
\text { proposal of norms by institutions and their approval by CONCAR. } \\
\text { In relation to metadata, there are complex standards to meet } \\
\text { the wide range of cartographic products produced - they need } \\
\text { expert knowledge to be documented. In Brazil, the MGB Profile } \\
\text { is approved by CONCAR. Given that many times data is } \\
\text { produced on a regular basis by some institutions, the process } \\
\text { of creating metadata can be standardized and executed with } \\
\text { specialized technical knowledge in each institution. }\end{array}$ & $\begin{array}{l}\text { Guidelines and standards: Standards and specifications proposed by the } \\
\text { INDE-BR should be adopted, both the technological aspects and interoperability, } \\
\text { as those concerning data production techniques, in order to have the academic } \\
\text { spatial data production as a contribution to the update of the data in the country. } \\
\text { However, science is responsible for creating technical and technological } \\
\text { subsidies to the proposition of new standards or adaptation of international } \\
\text { standards to the national scenario. In relation to metadata, summarized versions } \\
\text { may be used, but additional elements or integration with other standards may } \\
\text { be required, in order to take account of specific aspects of academic research. } \\
\text { As users do not have specialized knowledge, it is necessary to create mechanisms } \\
\text { to facilitate their documentation and encourage their use. Also there are } \\
\text { standards for metadata. The MGB Profile has been considered sufficiently } \\
\text { detailed up to now. Therefore, it can also be applied to SDI. }\end{array}$ \\
\hline $\begin{array}{l}\text { Quality: INDE-BR's guidelines and standards are defined by } \\
\text { official departments designated for this purpose. They are } \\
\text { responsible for the quality and consistency of the geospatial } \\
\text { data they distribute. } \\
\text { The technical specification for quality control of geospatial data } \\
\text { (ET-QCDG), in accordance with ISO 19157, describes how to } \\
\text { report the quality of the products of land mapping using } \\
\text { standardized procedures. The quality information are described } \\
\text { by metadata so that users can assess the suitability of the data } \\
\text { for the requested use. }\end{array}$ & $\begin{array}{l}\text { Quality: For the data to be included in the INDE-BR, they must meet the } \\
\text { adopted standards (consistency), besides having a satisfactory level of } \\
\text { compliance with these standards (quality). The academic SDIs must meet } \\
\text { both the norms, specifications and standards recommended by the INDE- } \\
\text { BR, and the documentation through metadata, aiming at the production of } \\
\text { their geospatial data to be integrated afterwards. Given that quality refers to } \\
\text { the suitability of the data to be utilized by users, it is of paramount importance } \\
\text { that a profoundly detailed documentation of metadata becomes usual to } \\
\text { researchers during the process of generation of geospatial data. }\end{array}$ \\
\hline $\begin{array}{l}\text { Legislation: INDE-BR was established by a decree, therefore, } \\
\text { is mandatory to federal government institutions and optional } \\
\text { for the institutions of the other levels of the government. The } \\
\text { INDE-BR is in line with the Open Data Policy in Brazil, and it } \\
\text { is recommended to observe this policies' mechanisms for } \\
\text { ensuring access to information (E-Ping, access to information } \\
\text { law and INDA). }\end{array}$ & $\begin{array}{l}\text { Legislation: Universities of all levels must also meet the legislation, both with } \\
\text { respect to the INDE-BR and to the mechanisms for ensuring access to } \\
\text { information, except for the research research that may protect intellectual } \\
\text { property. To become a INDE-BR's node, signing the term of agreement the } \\
\text { INDE-BR is essential. In the case of universities, the rector of each institution } \\
\text { is responsible to sign the term. } \\
\text { Additionally, the interested academic SDIs should meet five functionalities } \\
\text { required by INDE-BR: (1) the storage of geospatial data in geographic } \\
\text { databases or file system; (2) the storage of geospatial metadata in a local } \\
\text { catalog, available for access and retrieval through a catalog service; (3) the } \\
\text { recovery of geospatial data stored in the file system or through download; (4) } \\
\text { the visualization of geospatial data stored through maps service to provide } \\
\text { images intended for previewing in browsers; (5) the location and retrieval of } \\
\text { geospatial metadata stored in the local catalog via Web services. For this } \\
\text { end, there have to be internal norms in universities for the mandatory deposit } \\
\text { of geospatial data of research - as it is done for theses and dissertations. }\end{array}$ \\
\hline $\begin{array}{l}\text { Transparency and copyright: In Brazil, as the geospatial data } \\
\text { are produced with subsidies from tax collections, these data are } \\
\text { public and available with no costs - except for confidentiality } \\
\text { issues. However, the INDE-BR requests the participation of } \\
\text { actors that are not part of the public sphere. Questions concerning } \\
\text { copyright, restrictions, responsibilities and use licenses are } \\
\text { discussed by the Subcommittee on Legislation and Guidelines } \\
\text { (SLN) and by the spatial data subcommittee (SDE) of CONCAR. } \\
\text { Applicable results have not been published yet. }\end{array}$ & $\begin{array}{l}\text { Transparency and copyright: As public institutions, financed with subsidies } \\
\text { from tax collection, public universities also must return to society their } \\
\text { production, free of charge. The copyright provided under law } n^{\circ} 9.610 \text { of } \\
19 / 02 / 1998 \text { and RN- } 034 / 2014 \text { of CNPq was enshrined. } \\
\text { Regarding private institutions, the copyright provided under law } n^{\circ} 9.610 \text { must } \\
\text { be also observed. }\end{array}$ \\
\hline
\end{tabular}

Figure 2: Characterization of Academic SDIs in Brazil 


\section{Methodology}

The Federal University of Paraná (UFPR), based in Curitiba - Paraná, is the oldest Brazilian university, founded on December 19, 1912. According to its Statute (Brasil 2018), UFPR is an autarchy under a special regime with administrative, financial, didactic and disciplinary autonomy.

In 2016, its Teaching, Research and Extension structure consisted of 135 Undergraduate Programs, 129 Stricto Sensu Graduate Programs, 79 Master's Programs, 50 Doctoral Programs most with Capes concepts of 4 and 5 -, among other activities (Brasil 2016).

A structure of such size and complexity justifies the proposed deployment of an academic SDI to be initiated by a part of this structure. The Earth Sciences Department is one of the eleven academic departments of UFPR and consists of four stricto sensu graduate programs, namely: Geodetic Sciences, Environmental and Exploratory Geology, Geography, and Coastal and Oceanic Systems.

In order to begin the process of implementation of the UFPR academic SDI, a survey of a sample of theses and dissertations of the graduate programs of the Earth Sciences Department was carried out. Subsequently, the metadata of the areas under study and publications were surveyed and made available as a catalogue through GeoNetwork. The standards recommended by INDE-BR were adopted and open source software was used.

\subsection{Survey of Theses and Dissertations}

The survey of theses and dissertations was carried out through the collection of data available on the websites of the four aforementioned graduate programs. With these data, the files of the publications (*.pdf format) were searched and downloaded using the UFPR Institutional Digital Repository website in order to have the metadata surveyed, analyzed, and registered.

\subsection{Metadata Survey of the Fields of Study and of Publications}

As it was impossible to obtain the geospatial data (Given the fact that there is neither a formal requirement to deposit geospatial data nor a way to reach the researchers who have completed their studies, this survey of metadata was carried out.) generated by the research, metadata referring to the areas of study were catalogued. In addition to these, metadata regarding dissertations and theses, those included in the catalogues used by the libraries and repositories, were also catalogued.

The metadata survey of the areas of study was performed based on the Brazilian Geospatial Metadata Profile (MGB Profile) in its summarized version. All 23 elements were used, including the mandatory, conditional, and optional ones. The Figure 3 shows these elements and additionally the Dublin Core standard elements used for the publications. 


\begin{tabular}{|c|c|c|c|c|c|c|c|c|c|}
\hline \multicolumn{2}{|r|}{ Element } & \multirow{2}{*}{\begin{tabular}{c|} 
Obligation \\
Mandatory
\end{tabular}} & \multirow{2}{*}{$\begin{array}{l}\text { Spatial } \\
\text { Yes }\end{array}$} & \multirow{2}{*}{$\begin{array}{c}\text { Standard } \\
\text { MGB Profile }\end{array}$} & \multirow{2}{*}{\multicolumn{2}{|c|}{$\begin{array}{c}\text { Element } \\
\text { Type of spatial representation }\end{array}$}} & \multirow{2}{*}{$\begin{array}{c}\text { Obligation } \\
\text { Optional }\end{array}$} & \multirow{2}{*}{$\begin{array}{l}\text { Spatial } \\
\text { Yes }\end{array}$} & \multirow{2}{*}{$\begin{array}{c}\text { Standard } \\
\text { MGB Profile }\end{array}$} \\
\hline \multirow{17}{*}{ 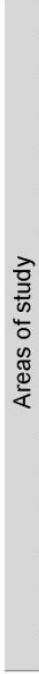 } & Title & & & & & & & & \\
\hline & Date & Mandatory & Yes & MGB Profile & \multirow{5}{*}{ 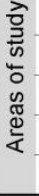 } & Lineage & Optional & Yes & MGB Profile \\
\hline & Responsible (spatial data) & Mandatory & Yes & MGB Profile & & Online access & Optional & Yes & MGB Profile \\
\hline & Language & Mandatory & Yes & MGB Profile & & Metadata identifier & Optional & Yes & MGB Profile \\
\hline & Thematic category & Mandatory & Yes & MGB Profile & & Name of the metadata standard & Optional & Yes & MGB Profile \\
\hline & Abstract & Mandatory & Yes & MGB Profile & & Version of the metadata standard & Optional & Yes & MGB Profile \\
\hline & Distribution format & Mandatory & Yes & MGB Profile & \multirow{11}{*}{ 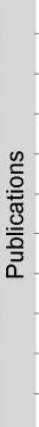 } & Institution & Mandatory & No & Dublin Core \\
\hline & Reference system & Mandatory & Yes & MGB Profile & & Department & Mandatory & No & Dublin Core \\
\hline & Date of metadata & Mandatory & Yes & MGB Profile & & Stricto sensu graduate program & Mandatory & No & Dublin Core \\
\hline & Responsible (metadata) & Mandatory & Yes & MGB Profile & & Year & Mandatory & No & Dublin Core \\
\hline & Status of metadata filling & Mandatory & Yes & MGB Profile & & Degree & Mandatory & No & Dublin Core \\
\hline & Geographical extension & Conditional & Yes & MGB Profile & & Student advisor/Co-advisor & Mandatory & No & Dublin Core \\
\hline & Character code (spatial data) & Conditional & Yes & MGB Profile & & Title of the study & Mandatory & No & Dublin Core \\
\hline & Language (metadata) & Conditional & Yes & MGB Profile & & Date of defense & Mandatory & No & Dublin Core \\
\hline & Character code (metadata) & Conditional & Yes & MGB Profile & & Date of approval & Mandatory & No & Dublin Core \\
\hline & Spatial resolution & Optional & Yes & MGB Profile & & Exam committee & Mandatory & No & Dublin Core \\
\hline & Temporal and atimetric extension & Optional & Yes & MGB Profile & & Keywords & Mandatory & No & Dublin Core \\
\hline
\end{tabular}

Figure 3: Catalogued metadata

\subsection{Metadata Description}

Among the mandatory elements were:

- Title: it refers to the title of the map. Most maps or geospatial datasets (GDS) generated by the publications presented no titles. For these cases, the title of the publication was used.

- Thematic Category: it referred to classification 5.2.18. MD_Topic Category Code of Attachment 5.2. Controlling Lists of MGB Profile Codes (CONCAR 2009, pp. 122124).

- Abstract: the abstract of the publication was utilized.

- Distribution Format: *.pdf, which is the distribution format of the publication. It contained information about geospatial data.

- Reference System: it referred to the reference system, scale, and projection of the data. Many published studies did not inform the reference system. Such cases were registered as WGS84 because they were considered identical to the Brazilian official reference system SIRGAS 2000 for all practical purposes (IBGE 2015).

Furthermore, many publications did not inform the scale. As this is a mandatory metadata, the approximate scales were inferred according to the scope of the area under study and based on the standard scales of topographic cartography. 
Among the conditional elements were:

- Geographical Extension: it referred to the bounding rectangle of the areas of study. The areas of study of the publications included various reference systems. This way, to standardize the insertion of their coordinates on GeoNetwork, a geographic database (GDB) was created. The WGS84 reference system and the cartographic base of the Brazilian Institute of Geography and Statistics (IBGE) were used in the 1:5.000.000 scale. The generated coordinates were used to complete the field "geographic bounding box" in GeoNetwork. This process enabled the generation of the WMS (Web Map Service) for viewing the bounding rectangles, which can be hereafter used to join the INDE-BR. In this process, the QGIS Desktop 2.12.1 software and the PostgreSQL version 9.4 and PostGIS version 2.2database were used.

Among the optional elements were:

- Spatial resolution: it referred to resolution information for remote sensing (SR) images.

- Temporal and Altimetric Extension: it referred to the period of time for which the GDS is valid. The time and altitude intervals were reported for data produced with historical series.

- Type of Spatial Representation: it referred to classification 5.2.17. MD_Spatial Representation Type Code of attachment 5.2. Controlling Lists of MGB Profile Codes (CONCAR 2009, pp. 121-122).

- Lineage: it referred to the description of the history of data production. Descriptions of the original data provided by other institutions and/or the processes and methods adopted for the production of geospatial data were used.

It should be noted that the lineage is one of the main metadata for assessing data quality. Regarding the academic SDI, it is certainly part of the Methodology section of theses and dissertations. This section involves the description of inputs, equipment, software, hardware, formats, resolutions, dates, methods and processes used to generate GDS, as well as the purpose for which the data was produced.

MGB profile (CONCAR 2009, pp. 130-138) details what the minimal descriptions for geospatial data lineage are in attachment 5.4-Guidelines for Lineage Fill and Quality Reports (to the major stages of the main production processes). It is highly recommended to observe these guidelines and descriptions during the data production and to document them in the Methodology, in case of publications, or, directly in the Lineage, in case of metadata. This must be done in order to ensure the assessment of the quality of the data produced by scientific research in universities. 
- Online Access: it referred to the address to access and to download the publication on the website of the Institutional Digital Repository of UFPR (dspace.c3sl.ufpr.br/dspace).

Metadata regarding the publications were added as a way to connect the area under study to the data generated by the author. The metadata survey from the publication was based on the Dublin Core standard. The described set of metadata can be considered the lowest common denominator for representing a resource and, in addition, it is equivalent to a cataloguing record (Souza, Vendrusculo and Melo 2000). All elements of the Dublin Core have not been catalogued because ISO 19115 itself derived from this standard and thus bears most elements. In the section 'Content', elements such as Title, Keywords and Type were catalogued. In the section 'Intellectual Property', the elements Publisher/Editor and Contributor. Finally, in the section 'Instantiation', the Date was the element taken into consideration. These elements were distributed in 13 pieces of information, obtained from the readings of the cover, the term of approval and the abstract of publications. They are:

- Cover: Institution; Department; Stricto Sensu Graduate Program; Year; Degree (master's or doctorate); Student; Advisor / Co-Advisor and Title of the study.

- Term of approval: Date of Defense; Date of Approval; Exam Committee.

- Abstract: Keywords.

When the text had no keywords, they were added from significant terms that appeared in the title and in the abstract.

After having completed the survey of the metadata, regarding the areas under study and the publications, it was made available as a catalogue.

\subsection{Availability of Metadata in a Catalogue}

The registration of metadata was provided as a catalogue via the geoportal on GeoNetwork server version 3.0.2 (metadata server) - the same used to construct the metadata catalogue INDEBR.There were filled in the 23 elements of summarized version of the MGB profile, as it would not be possible to obtain all the 76 elements of the complete profile.

Regarding to the GeoNetwork search tool, it searches the terms in the fields "Title", "Abstract", "Keywords" and "Thematic Category". Accordingly, all terms likely to be searched should be written in these fields. In the field "Keywords", all the geographic names (location, city, state, country) of the areas under study have been inserted because GeoNetwork has no way to find them in the field "Geographical Extension". That field can have the coordinates and the bounding rectangles inserted; however, there is no identifier that records the geographical names. 


\section{Results and Discussion}

The survey of the theses and dissertations, especially of the metadata regarding the areas under study and publications, allowed both their availability in a catalogue and the analysis of the missing metadata. It also favored the distribution of research in a given geographic area as ways of demonstrating the importance of the existence of metadata in the context of the academic SDI.

\subsection{Survey of Theses and Dissertations}

In the survey of theses and dissertations, it was observed that each of the programs offered the names of students and the corresponding data in different ways. Several publications were not found and there was no justification whatsoever, either on the Graduate program websites or on the Digital Repository of UFPR.

The survey of the theses and dissertations resulted in the numbers described in Figure 4. It was constituted of a sample of seven years for each program, beginning from the most recent years.

\begin{tabular}{|l|c|c|c|c|c|} 
& $\begin{array}{c}\text { Number of } \\
\text { Studies } \\
\text { Surveyed }\end{array}$ & Thesis & Dissertations & $\begin{array}{c}\text { Number of } \\
\text { Studies } \\
\text { Registered }\end{array}$ & $\begin{array}{c}\text { *.pdf File } \\
\text { Not Found }\end{array}$ \\
\hline Geodetic Sciences & $\mathbf{1 0 9}$ & 30 & 79 & $\mathbf{6 7}$ & $\mathbf{3 9 \%}(\mathbf{4 2})$ \\
\hline Environmental and Exploratory Geology & $\mathbf{5 8}$ & 3 & 55 & $\mathbf{4 5}$ & $\mathbf{2 2 \%}(\mathbf{1 3 )}$ \\
\hline Geography & $\mathbf{4 0}$ & 15 & 25 & $\mathbf{4 0}$ & $\mathbf{0 \%}(\mathbf{0})$ \\
\hline Coastal and Oceanic Systems & $\mathbf{1 0 7}$ & 0 & 107 & $\mathbf{1 0 1}$ & $\mathbf{6 \%}(\mathbf{6})$ \\
\hline Total & $\mathbf{3 1 4}$ & $\mathbf{4 8}$ & $\mathbf{2 6 6}$ & $\mathbf{2 5 3}$ & $\mathbf{1 9 \%}(\mathbf{6 1 )}$ \\
\hline
\end{tabular}

Figure 4: Results of the Survey of Theses and Dissertations

The Graduate Program in Geodetic Sciences (PPGCG) at UFPR was founded in 1971. Data from 1973 to 2012 available on the website were collected, totaling 334 studies (258 dissertations and 76 theses). Of this total, 109 publications from 2006 to 2012 were surveyed. However, 42 were not found (pdf documents); therefore, 67 metadata publications were then registered.

The Graduate Program in Environmental and Exploratory Geology (PPGG) at UFPR was founded in 1992. Data from 1995 to 2014 available on the website were collected, totaling 209 studies (162 dissertations and 47 theses). Of this total, 58 publications were surveyed from 2008 to 2014. However, 13 of them were not found; Therefore, 45 metadata publications were then registered.

The Graduate Program in Geography (PPGGeografia) at UFPR was founded in 1999. Its website (www.ppggeografia.ufpr.br) was under construction during the two years in which this research was being carried out. Data were collected and the 5-year-old metadata (from 2009 to 2013) were registered through worksheets provided by the secretarial course, totaling 40 studies (25 dissertations and 15 theses). 
The Graduate Program in Coastal and Oceanic Systems (PGSISCO) at UFPR was founded in 2006. Data available on the website from 2007 to 2014 were collected, totaling 107 dissertations (doctoral activities began in 2011). However, six of these publications were not found. Thus, 101 metadata dissertations were registered.

An analysis of the proportional amount of publications in each program revealed that the Geodetic Sciences program obtained the highest percentage of pdf documents of the publications which were not found (39\%), followed by the Environmental and Exploratory Geology program (22\%) and the Coastal and Oceanic Systems program (6\%). Although the Geography course did not present any missing files among the analysed publications, it does not have an organized listing and publications available on its website.

The lack of pdf documents is noteworthy since the deposit of the publications is mandatory and official. These figures do not allow an in-depth analysis, but they do give an idea of the difficulty of retrieving the historical metadata and how difficult it may be to recover the geospatial data itself.

\subsection{Metadata Survey of the Areas of Study and of Publications}

The numbers resulting from the survey of the metadata of the areas of study and publications are shown in Figure 5, which describes the missing metadata for the two classes of metadata.

\begin{tabular}{|l|c|c|c|c|} 
& \multicolumn{2}{c|}{ Publications } & \multicolumn{2}{c|}{ Areas Under Study } \\
\cline { 2 - 5 } & $\begin{array}{c}\text { Term of } \\
\text { Approval } \\
\text { Missing }\end{array}$ & $\begin{array}{c}\text { Keywords } \\
\text { Missing }\end{array}$ & $\begin{array}{c}\text { Bounding } \\
\text { Rectangle } \\
\text { Missing }\end{array}$ & $\begin{array}{c}\text { Reference } \\
\text { System } \\
\text { Missing }\end{array}$ \\
\hline Geodetic Sciences & $67 \%$ & $15 \%$ & $15 \%$ & $51 \%$ \\
\hline Environmental and Exploratory Geology & $29 \%$ & $18 \%$ & $40 \%$ & $60 \%$ \\
\hline Geography & $\mathbf{5 \%}$ & $\mathbf{5 \%}$ & $\mathbf{4 5 \%}$ & $\mathbf{6 8 \%}$ \\
\hline Coastal and Oceanic Systems & $\mathbf{2 6 \%}$ & $\mathbf{4 \%}$ & $\mathbf{2 1 \%}$ & $\mathbf{6 3 \%}$ \\
\hline
\end{tabular}

Figure 5: Missing Metadata - Comparison

The missing elements with regard to the metadata of the publications were the Term of Approval and the Keywords. When there was no Term of Approval, data such as the Exam Committee, Date of Defense, and Date of Approval of the thesis or dissertation could not be registered. These elements are of utmost importance in order not to compromise the result of the search. If there is no date, for instance, only the year of the publication will be shown, not responding to the command of the reader. On the other hand, if there is no information about the Exam Committee, the accreditation of data is compromised since the information of all the examiners who assessed the research is unavailable.

It is noteworthy to mention that the academic geospatial data carries the quality seal conferred by peer review, which is the process by which researchers submit their research to the scrutiny of other experts in the same area of interest (the peers). These experts assess 
methodology, results and conclusions presented by the researchers, judging the originality and credibility of the study. Moreover, criteria involving consistency between data and interpretation, and innovation of the study are also assessed. In order to maintain the quality standards of scientific publications, peer review is performed by authors, reviewers, readers, and editors, which gives the research the unique characteristic of self-control and self-correction to the development of Science (Nóbrega and Loh 2013).

As for the Keywords, their absence jeopardizes the very identification of the publication, since whoever registers the metadata - if not the researcher him/herself - may not have the necessary expertise to select the most appropriate terms.

For metadata of the areas under study, the missing elements were the Bounding Rectangle and the Reference System. In the absence of the Bounding Rectangle, which is the area under study itself, it was necessary to read the entire thesis or dissertation to identify it. Some publications mentioned that the research had had its data collected in a certain location, yet with no identification of the coordinates. In other cases, the researcher used a map to show the area under study, but it failed to show the coordinates, the reference system and the scale of representation. In both situations, the bounding rectangle was implied. Nevertheless, this is not an ideal situation to Science. The absence of the Reference System compromises the georeferencing of data and the very assessment of the usefulness of the data when shared. In its absence, the Reference System also had to be inferred. Additionally, it is possible to have a series of GDS with different characteristics for the same area under study. The registration of metadata for each set of Geospatial Data would be the ideal scenario for scientific research.

The analysis demonstrated though that many studies did not describe these elements because they adopted information from various sources. The name of the sources was cited, but the data lineage was not. For instance, the researcher used an IBGE database, but neither cited the year nor the reference system nor the scale. In many cases, researchers reported having developed a GIS (Geographic Information System). However, they have not informed the year, the reference system, nor the scale of each one of the bases used, neither have they described how they integrated or analyzed the data.

If data were manipulated and analyzed, as occurred with many thesis indexed in this research, metadata would be able to include technological and methodological details of the research, such as computational environment, software, algorithms. In this regard, it is noteworthy to consider how automation could be done in the capture of metadata as well as an evaluation of metadata quality and documentation.

The absence of some metadata may be explained by the fact that some research concern mathematical models, conceptual models or methodologies for production processes. Yet few cases were observed under these conditions.

When analyzing the proportional amount of publications in each program (Figure 5), some numbers demonstrate the lack of essential metadata elements that are part of the description of the scientific method. Regarding the graduate program in geodetic sciences, half of the publications have not described the reference system used. The other programs have not differed much: more than half of the publications have not described it either. Additionally, the absence of the bounding rectangle was verified in several cases, especially in the graduate programs in environmental and exploratory geology and in geography. This result reinforces the need for researchers themselves to fill in the metadata and to store data during, not after, the conduction of any research. 


\subsection{Availability of metadata in a catalog}

The registration of the metadata of the publications and their respective areas of study resulted in their cataloging through the geoportal in the GeoNetwork environment.

As seen on the home screen (Figure 6), one can do a text or a topics search. For a search using date and map, one should click on Map and/or Search on the top left side of the window. For the four search engines, GeoNetwork provides a screen featuring titles, abstracts and thumbnails of publications related to the term searched.

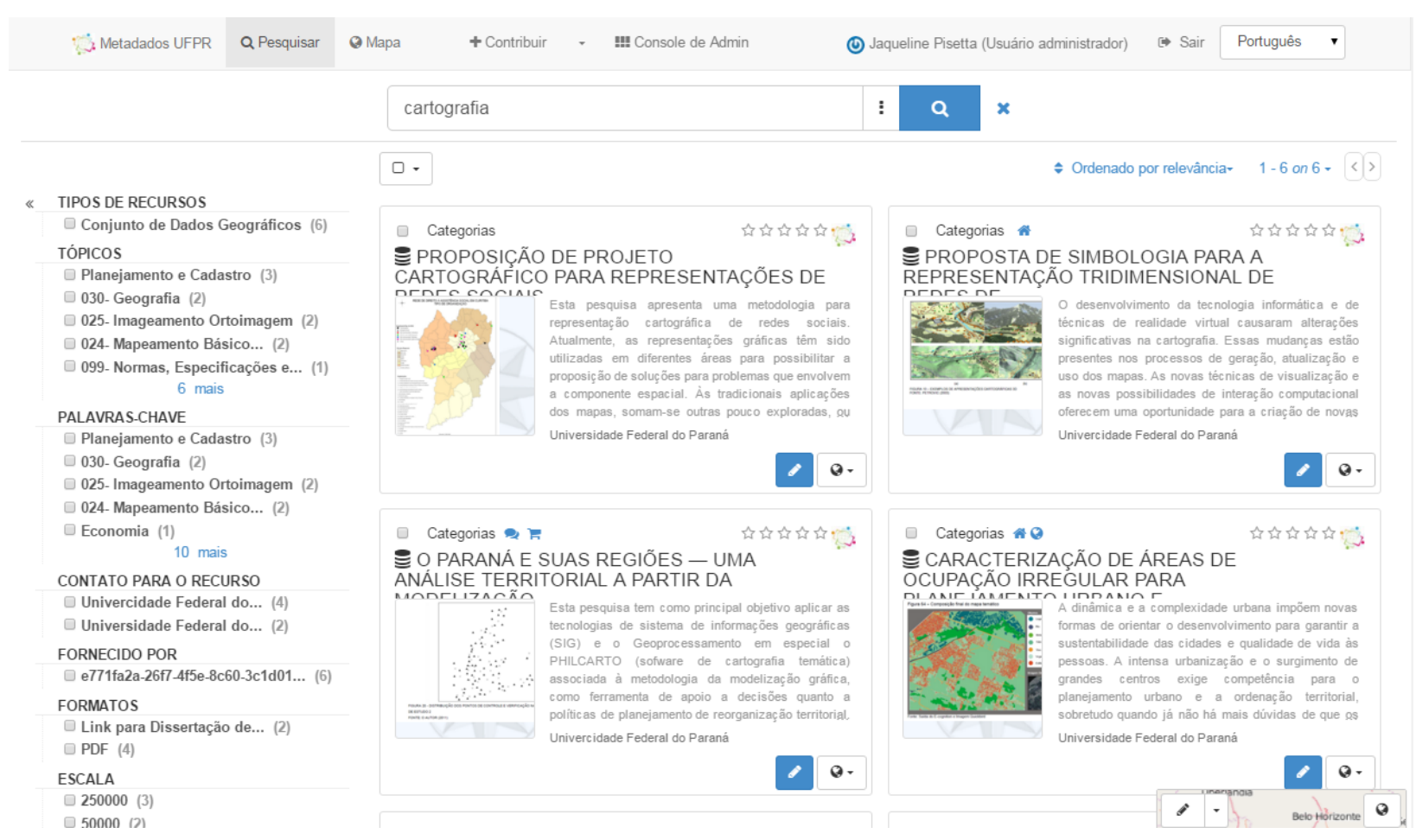

Figure 6: Search engine results page on Geoportal.

By clicking on the publication of choice, the system generates a window showing metadata about the specific text (Figure 3). In the field Format, on the technical information area, there is a link that redirects the user to the UFPR Institutional Digital Repository, where one can download the thesis or dissertation (pdf document) regarding the metadata described. The user can also save a file that features the metadata for the selected publication, automatically generated by GeoNetwork (Figure 7).

The GeoNetwork edition area allows the system managers to include, edit, import, and delete metadata and records. 


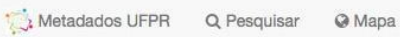 \\ PROPOSIÇAO DE PROJETO CARTOGRAFICO PARA REPRESENTAÇOES DE REDES SOCIAIS}

Atualizado: a month ago

Esta pesquisa apresenta uma metodologia para representação cartográfica de redes sociais. Atualmente, as representaçōes gráficas têm sido utilizadas em diferentes áreas para possibilitar a proposição de soluçōes para problemas que envolvem a componente espacial. Às tradicionais aplicaçōes dos mapas, somam-se outras pouco exploradas, ou até mesmo nāo imaginadas. Como exemplos podem-se citar o mapeamento de informaç̄es sociais, xptivas le socio assistencis ple ecesśrio compreender quais são as análises realizadas pelos especialistas em Redes Socieis com a utilização de grafos para conhecer os atributos das redes, bem como de cada um de seus componentes, hierarquias e posiçōes na malha de articulação; e como os especialistas propōem açōes sobre as redes sociais, considerando suas caracteristicas a partir destas análises. Por isso este trabalho apresenta a aplicação do connecimento técnicocientifico da Cartografia na representação de redes sociais, visando soluçōes de representaçōes espaciais para subsidiar a análise dos elementos componentes das redes e seus relacionamentos. Os resultados indicaram que os especialistas da área conseguiram realizar os estudos e avaliaçōes necessárias com a espacializaçāo dos dados principalmente conseguiram aprimorar suas análises em relação à rede em estudo. Departamento: Geomática. Curso de Pós Graduação Stricto Sensu: Ciências Geodésicas. Data da Defesa: 22 de Novembro de 2007. Data da Aprovaçāo: 22 de Novembro de 2007. Orientador: Profa. Dra. Luciene Stamato Delazari.

Banca Examinadora: Profa. Dra. Samira Kauchakje (PUC-PR), Prof. Dr. Daniel Rodrigues dos Santos (UFPR).

\section{downloadsAndResources}

Online Web Map Context file

Abrir link

\section{Sobre este recurso}

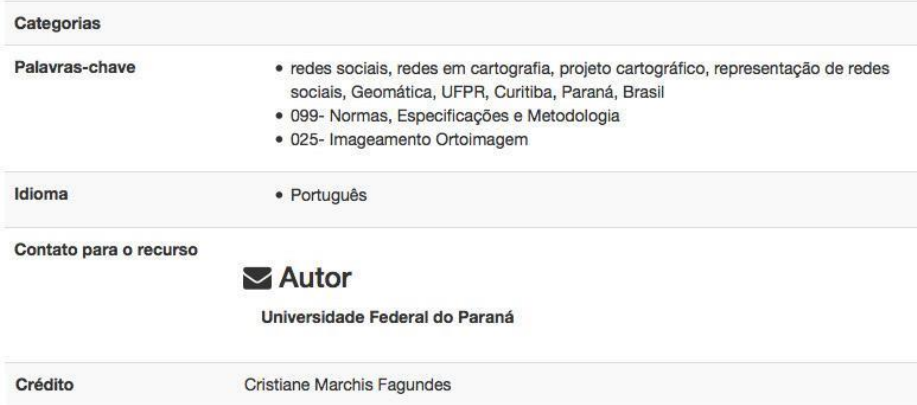

\section{Informação técnica}

\begin{tabular}{l|l}
\hline Escala & $\bullet 50000$ \\
\hline $\begin{array}{l}\text { Sistema de referência de } \\
\text { coordenadas }\end{array}$ & $\bullet::$ WGS84 \\
\hline Formato & Lnk para Dissortaçalo de Mestrado em formato PDF no Repositorro Institucional da UFPR \\
\hline
\end{tabular}

\section{Informações do metadado}

(1) Baixar metadado

\begin{tabular}{ll} 
Contato & $\begin{array}{l}\text { Editor } \\
\text { Universidade Federal do Paraná - } \\
\text { Laboratório Geoespacial Livre } \\
\text { opengeolab@gmail.com }\end{array}$ \\
\hline Idioma do metadado & - Português \\
\hline Identificador & 256 df4b5-6886-4fbe-9dda-b03a583c5dfa \\
\hline Sobre O Github Powered by geonetwork 3.0.2.0 it
\end{tabular}

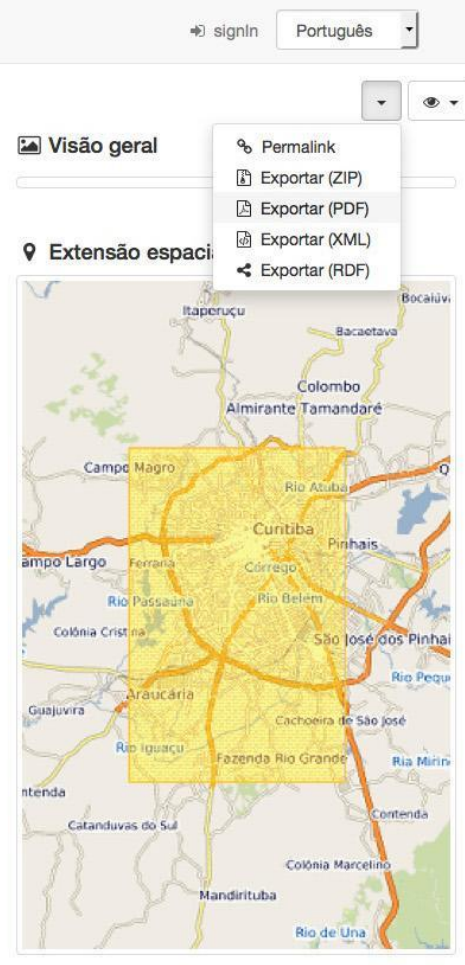

○ Extensão temporal Data de publicação 2007-11-15

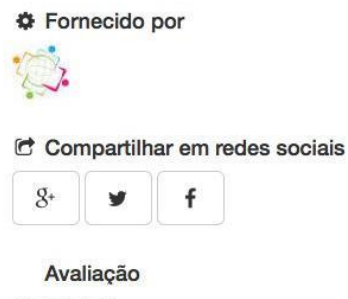

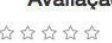

Figure 7: Detailed search engine results page on Geoportal. 
In addition to enabling access to data, the catalog allows users to observe other aspects and characteristics of research at UFPR, which can generate various analyses that are not part of the scope of this research, but can exemplify the importance of the existence of metadata. This is the case of spatial distribution of all registered research in Paraná, in Brazil and/or in the world. Figure 8 considers an example of this distribution for the graduate program in Geodetic Sciences globally. It demonstrates that research generated with geospatial data developed in the CentreNorth and East of Paraná abounds. Globally, there is some research in Europe.

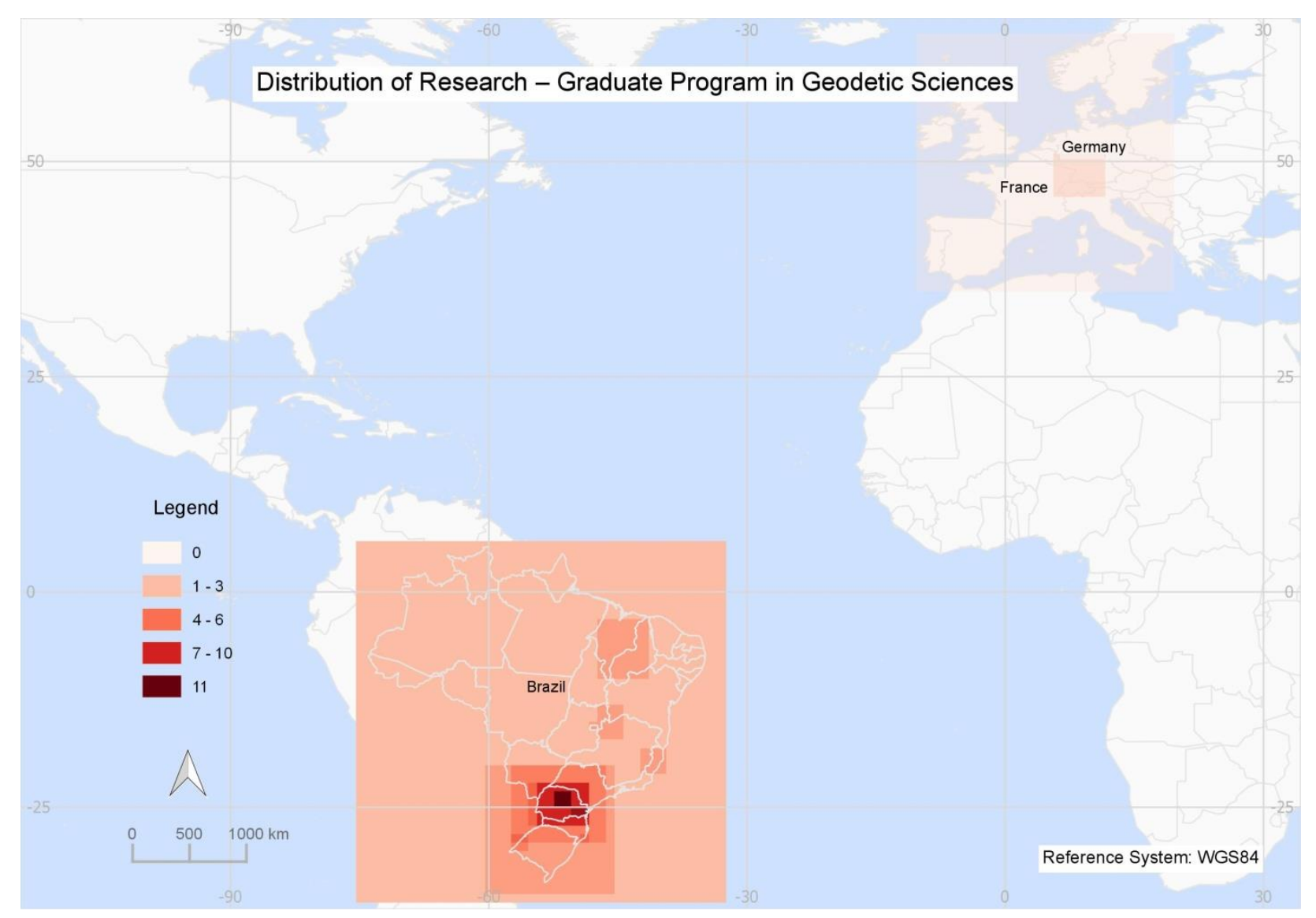

Figure 8: Distribution of research conducted in the graduate program in geodetic sciences.

\section{Final Remarks}

The present article exposed the results of a survey concerning the metadata of dissertations, theses, and their respective disciplines of UFPR's graduate programs in Geodetic Sciences, Environmental and Exploratory Geology, Geography, and Coastal and Oceanic Systems. It also presented the availability of such data in a catalog as an initial step for the implementation process of the academic SDI of UFPR.

These experiences constituted into the contribution of this research in a way that they demonstrated the possibility to facilitate access to academic geospatial data in a decentralized manner. Such facilitation was done by using protocols, specifications and standards already 
grounded by the international geospatial community. In addition, the research met the recommendations proposed by INDE-BR.

The objectives were also met in order to provide conceptual, methodological, and technological subsidies for the creation of SDIs in Brazilian universities.

The cataloging of historical metadata was found to be viable and to facilitate the dissemination of geospatial data to the scientific community. Moreover, the provision of metadata was verified to improve the research process. Therefore, it avoids the duplication of efforts and the use of resources on data that had been produced previously. Another finding of the study was that the ideal form of registering the metadata and uploading the data would be through the researchers themselves, who have the necessary information to do these actions. In order to ensure the quality and consistency of the metadata, and in the future, the data collected by the researches on the platform, it would be necessary a formal requirement by the university to deposit geospatial data, as is required for the theses and dissertations, and in the case of metadata the obligatory completion of mandatory metadata elements. In light of this, incentive policies, creation of standards for documentation, sharing of future data and metadata, training, and support infrastructure (staff and computers) are fundamental.

Thus, using free and open source software reduces deployment costs and allows sharing new functionalities. As a platform for cataloging metadata, GeoNetwork has met the expectations and, despite a few mishaps in the configuration, the new version has a lot of potential.

Thus, the present study investigated and assessed issues concerning the retrieval and cataloguing of geospatial metadata for a community composed of experts and users of related areas. Hence, it is recommended to broaden research on the use of spatial and non-spatial metadata by users of other programs.

The solution proposed for the provision and access to geospatial data, through an academic SDI, requires some training to persuade the academic community to, if possible, produce metadata while they are being produced. Finally, it urges to raise awareness about the importance of education in order to teach the notion of space.

The availability of consistent data and tools that allow viewing and manipulating data in the form of digital maps aims to empower and enable academic users, thus allowing the creation of visual representations. Within the SDI, experiences such as data visualization, search and analyses performing, and creation, annotation and sharing of maps would favor the construction of a social and educational experience on the use of geospatial data.

From the literature review, it was possible to notice that a great increase in the number of academic SDIs has been taking place, both international and national, including the signing of the term of agreement to INDE-BR. This growth plays a fundamental role in the technological issue, collaborating in all aspects related to the guidelines of the Open Science movement.

In comparison to the approaches of the SDIs referenced in section one, the academic SDIUFPR is an independent and decentralized initiative because it is not associated with a network of libraries and still lacks resources and institutional support of the university, is collaborative because its functionalities are being developed through masters, doctorates and scientific/technological research using few resources and free software and adapted to the Brazilian reality. In addition, Brazilian academic SDIs are collaborating with each other through a national network (called Rede IDEA) and fostering discussion about their importance in national meetings. 


\section{Acknowlegment}

The authors gratefully acknowledge CAPA (Centro de Assessoria de Publicação Acadêmica da UFPR). The authors also acknowledge the support provided by CAPES (Coordenação de Aperfeiçoamento de Pessoal de Nível Superior).

\section{Author's Contribution}

Both authors contribute equally.

\section{REFERENCES}

Arzberger, P., Schroeder P., Beaulieu A., Bowker, G., Casey, K., Laaksonen, L., Moorman, D., Uhlir, P., Wouters, P. 2004. Promoting access to public research data for scientific, economic, and social development. Data Science Journal, 3.pp. 135-153.

Barea, M., Carrara, P., Guimet, J., Koukourouvli, N., Pascual, V., Pepe, M., Redondo, M., Simos, D., Vaitis, M. 2011. The Development of a Trans-national Academic SDI: Experiences, Realisations and Perspectives. Proceedings of INSPIRE Conference, Edimburg, 2011. pp.1-24.

Berman, F. and Cerf,V. 2013. Who Will Pay for Public Access to Research Data? Science, 341 (6146),pp. 616-617.

Bernard, L., Mäs, S., Müller, M., Henzen, C. \& Brauner, J. 2014. Scientific geodata infrastructures: challenges, approaches and directions. International Journal of Digital Earth, 7(7), pp. 613-633.

Borba, R. L. R., Strauch, J. C. M. and Souza, J. M. 2014.Cartografia Ubíqua e Infraestrutura de Dados Colaborativa para Gestão de Eventos Geográficos.In:XXVI Congresso Brasileiro de Cartografia. Gramado, Brazil, 03-07 August 2014, SBC/UFRGS.

Brasil (1984)."Decreeof 89.817 20/06/1984, establishingthe Regulatory Instructions of the National Cartography Technical Standards. Available at: http://www.planalto.gov.br/ccivil_03 /decreto/1980-1989/D89817.htm.[Acessed 03 September 2018].

Brasil. 1988. Constitution of the Federative Republic of Brazil of 1988. Vade Mecum Acadêmico de Direito, Editora Rideel, 8ª edição. São Paulo, 2009.

Brasil. 2008. Decree of 6.666 27/11/2008, establishing National Spatial data infrastructure INDE. Available at: <http://www.planalto.gov.br>. [Acessed 25 October 2017].

Brasil. 2011a. Conselho Nacional de Desenvolvimento Científico e Tecnológico (CNPq). Report of the Committee on Research integrity of CNPq. Available at: http:

memoria.cnpq.br/normas/lei_po_085_11.htm\#relatorio=. [Accessed25 December 2017].

Brasil. 2011b. Law 12.527 de 18/11/2011, Regula o acesso a informações previsto no inciso XXXIII do art. 5, no inciso II do $\S 30$ do art. 37 e no $\S 2 \circ$ do art. 216 da Constituição Federal. Available at: <http://www. planalto.gov.br>. [Acessed 3 September 2018]. 
Brasil.2012. Plano de Ação da Infraestrutura Nacional de Dados Abertos. Available at: http://notas.dados.gov.br/planodeacaoinda/. [Accessed 3September 2018].

Brasil. 2016. Relatório de Atividades UFPR 2016. Available at: http://www.ufpr.br. [Acessed 17 June2018].

Brasil. 2018. Estatuto da Universidade Federal do Paraná. Available at: http://www.ufpr.br. [Acessed 17 June 2018].

Brito, P. L., Souza, F. A., Camboim, Si. P., Giannotti, M. A. 2014. Primeiros Passos para a Implementação de uma IDE Universitária. In:Anais do V Simpósio Brasileiro de Ciências Geodésicas e Tecnologia da Geoinformação - SIMGEO. Recife-PE, November, 2014, pp. 77-84.

Campbell, Eric. G.andBendavid, E. 2003. Data-sharing and data-withholding in genetics and the life sciences: Results of a national survey of technology transfer officers. Journal of Health Care Law Policy, 6,pp. 241-255.

Coetzee, S., Steiniger, S., Köbben, B., Iwaniak, A., Kaczmarek, I., Rapant, P., Cooper, A., Behr, F-J., Schoof, G., Katumba, S., Vatseva, R., Sinvula, K., and Moellering, H. 2017. The Academic SDITowards understanding spatial data infrastructures for research and education. In: Peters, M. ed. Advances in Cartography and GIScience. Lecture Notes in Geoinformation and Cartography. ICACI 2017. pp. 99-103. Springer.

CONCAR (Comissão Nacional de Cartografia). 2009. Perfil de Metadados Geoespaciais do Brasil (Perfil MGB). Available at: http://www.concar.ibge.gov.br/arquivo/Perfil_MGB_ Final_v1_homologado.pdf. [Acessed 15 June 2018].

CONCAR (Comissão Nacional de Cartografia). 2010. Plano de Ação para Implantação da Infraestrutura Nacional de Dados Espaciais - INDE. Available at: http://www.inde.gov.br. [Acessed 03 September 2018].

Davis Jr., C. A., Fonseca, F. T., Câmara, G. 2009. Infraestruturas de Dados Espaciais na Integração entre Ciência e Comunidades para Promover a Sustentabilidade Ambiental. Paper presented at the Workshop de Computação Aplicada à Gestão do Meio Ambiente e Recursos Naturais, 2009. Available at: http://homepages.dcc.ufmg.br/ clodoveu/files/100.40/AC049.

Fecher, B. and Friesike, S. 2014. Open Science: One Term, Five Schools of Thought. Opening Science. Bartling, S.and Friesike, S. eds.Springer, Cham.pp. 17-47.

Foster. 2018. "Open Science Definition". Available at: https://www.fosteropenscience. eu/taxonomy/term/100. [Acessed 15 June 2018].

Fronza, G. 2016.IDE Acadêmica: Construção de uma Infraestrutura de Dados Espaciais Colaborativa. Master's thesis, Universidade Federal do Paraná, 97p.

Hill, E.and Trimble, L. 2012. Scholars GeoPortal: A New Platform for Geospatial Data Discovery, Exploration and Access in Ontario Universities. IASSIST Quarterly, 36 (1), pp. 6-15.

IBGE (Instituto Brasileiro de Geografia e Estatística).2015. Nota Técnica Término do Periodo de Transição para Adoção no Brasil do Sistema de Referência Geocêntrico para as Américas (SIRGAS). Available at: ftp://geoftp.ibge.gov.br/documentos/geodesia/pdf/nota_tecnica_termino 
_periodo_transicao_sirgas2000.pdf. [Acessed 15 de Junho de 2018].

INDE (Infraestrutura Nacional de Dados Espaciais), 2018.Catálogo de Metadados da INDE. Catálogos por instituição. Available at: http://www.metadados.inde.gov.br/geonetwork /srv/por/main.home. [Acessed 25 June 2018].

Iosifescu-Enescu, I., Matthys, C., Gkonos, C., Iosifescu-Enescu, C. M. and Hurni, L. 2017. CloudBased Architectures for Auto-Scalable Web Geoportals Towards the Cloudification of the GeoVITe Swiss Academic Geoportal. ISPRS International Journal of Geo-Information, 6 (192), pp. 01-16.

Kethers, S., Shen, X., Treloar, A. E., Wilkinson, R. G. 2010. Discovering Australia's research data. In: Proceedings of the 10th annual joint conference on Digital libraries, pp. 345-348. ACM New York, USA.

Martins, E. F. 2008 Extensão como Componente Curricular: Oportunidade de Formação Integral e de Solidariedade. Ciências \& Cognição, 13, pp. 201-209.

Marwick, B., d'Alpoim Guedes, J., Barton, C. Michael.,Bates, L. A., Baxter, M., Bevan, A., Bollwerk, E. A., Bocinsky, R. K., Brughmans, T., Carter, A. K., Conrad, C., Contreras, D. A., Costa, S.,Crema, E. R., Daggett, A., Davies, B., Drake, B. L., Dye, T. S., France, P., Fullagar, R., Giusti, D., Graham, S., Harris, M. D., Hawks, J., Heath, S., Huffer, D., Kansa, E. C., Kansa, S. W., Madsen, M. E., Melcher, J., Negre, J., Neiman, F. D., Opitz, R., Orton, D. C., Przystupa, P., Raviele, M., Riel-Salvatore, J., Riris, P., Romanowska, I., Smith, J., Strupler, N., Ullah, I. I., Van Vlack, H. G., Van Valkenburgh, N., Watrall, E. C., Webster, C., Wells, J., Winters, J., and Wren, C. D. 2017. Open Science in Archaeology. The SAA Archaeological Record, 17(4), pp.8-14.

Medyckyj-Scott, D., Beedham, H., Missen, J., Abrahamson, P., Boyle, E., Mathys., T. 2004. GoGeo! Geo-Data Portal - Transition to Service.Final report to the JISC IE Programme, Edinburgh, 2004. 49 p.

Nóbrega, J. A. and Loh, W. 2013. Revisitando as Diretrizes para a Revisão por Pares.Journal of Brazilian Chemical Society, 24 (4), pp. 525-528.

Nosek, B. A., Alter, G., Banks, G. C., Borsboom, D., Bowman, S. D., Breckler, S. J., Buck, S., Chambers, C. D., Chin, G., Christensen, G., Contestabile, M., Dafoe, A., Eich, E., Freese, J., Glennerster, R., Goroff, D., Green, D. P., Hesse, B., Humphreys, M., Ishiyama, J., Karlan, D., Kraut, A., Lupia, A., Mabry, P., Madon, T. A., Malhotra, N., Mayo-Wilson, E., McNutt, M., Miguel, E., Levy Paluck, E., Simonsohn, U., Soderberg, C., Spellman, B. A., Turitto, J., VandenBos, G., Vazire, S., Wagenmakers, E. J., Wilson, R., Yarkoni, T. 2015. Promoting an open research culture: Author guidelines for journals could help to promote transparency, openness, and reproducibility. Science, 348 (6242), pp. 1422-1425.

Oliveira, P. F.and Ramos, J. A. S. 2013.Arquitetura e Desafios de uma Infrestrutura de Dados Espaciais para Setores da Universidade do Estado do Rio de Janeiro. In: Anais XVI Simpósio Brasileiro de Sensoriamento Remoto - SBSR (INPE). Foz do Iguaçu-PR, Brazil, 13-18 April2013, pp. 2525-2532. 
PRC - Publishing Research Consortium [online]. 2010. Access vs. Importance. (Powerpoint presentation, Ware, M. and Elsevier research team) October, 2010. Available at:

http://www.publishingresearchconsortium.com/index.php?option=com_content\&view=article\&i $d=114 \&$ Itemid $=575$.

Savage, C. J. and Vickers, A. J. 2009. Empirical Study of Data Sharing by Authors Publishing in PLoS journals. PLOS ONE 4(9): e7078. Available at: https://doi.org/10.1371/journal. pone.0007078.

Silva, E. S. and Camboim, S. P. 2018. Eliciting academic SDI requirements through a survey of user practices. Open Geospatial Data, Software and Standards,3(11), pp. 1-10.

Smyth, C. G. 2015.SDI - National to Global: perspectives from the UK academic sector. In: Proceedings of the pre-conference workshop of the 27th International Cartographic Conference: Spatial data infrastructures, standards, open source and open data for geospatial (SDI-Open 2015). Rio de Janeiro, Brazil, 20-21 August 2015, Brazilian Institute of Geography and Statistics (IBGE), pp. 12-18.

Souza, M. I. F. Vendrusculo, L. G. Melo, G. C. 2000. Metadados para a descrição de recursos de informação eletrônica: utilização do padrão Dublin Core. Ciência da Informação, 29(1), pp.93102.

Tenopir, C., Allard, S., Douglass, K., Aydinoglu, A. U., Wu, L., Read, E., Manoff, M., Frame, M. 2011. Data Sharing by Scientists: Practices and Perceptions. PLoS ONE 6(6), pp. 1-21. 